\title{
Does the Gap between Domestic and International Gold Price Affect Money Demand?: Evidence from Vietnam
}

\author{
Le Thanh TUNG ${ }^{1}$
}

Received: May 21, 2019 Revised: June 11, 2019 Accepted: June 14, 2019

\begin{abstract}
The paper aims to investigate the impact of the gap between domestic and international gold price on money demand in Vietnam, an emerging economy in the Asian region. We use a quarterly database collected from the first quarter of 2004 to the fourth quarter of 2016. The time-series database includes 52 observations. The money demand is represented by M2; Domestic income is the Gross domestic product at the constant prices of 1994; Inflation rate is calculated by the Customer Price Index from the General Statistics Office of Vietnam. The result confirms the existence of a long-term cointegration relationship between the money demand and the gap between domestic and international gold price as well as some variables including domestic income, inflation, and real exchange rate. The regression results also show that the gap between domestic and international gold price has a positive impact on money demand in the Vietnamese economy. Besides, the domestic income and international gold price have positive impacts on money demand while the inflation and real exchange rate are negatively related in the long run. This proves that the gap between the domestic and international gold price really has a positive impact on money demand in Vietnam during the study period.
\end{abstract}

Keywords: Gold Price, Money Demand, Domestic Income, Exchange Rate, Inflation.

JEL Classification Code: E41, E44, E51, E52, E58.

\section{Introduction}

Located in the Southeast Asia region, Vietnam has a motivated gold market which is amongst the countries with the highest demand worldwide. The Vietnamese people use gold as a traditional saving in year by year. Besides, in Vietnam, gold has been used as a money unit of account for exchange the high-value assets (e.g., automobile or real estate) or as a unit account for a transaction not involving gold. In order to against the high inflation rate over time, gold of value characteristic also makes it popular as a hedge against the depreciation of the domestic currency in Vietnam. The role of gold in Vietnam has been extended to a medium exchange of speculation, and betting on the gold

1 First Author and Corresponding Author. Lecturer, Faculty of Economics and Public Management, Ho Chi Minh City Open University, Vietnam [Portal Address: 97 Vo Van Tan Street, Ward 6, District 3, Ho Chi Minh City, 700000, Vietnam].

Email: tung.It@ou.edu.vn

() Copyright: Korean Distribution Science Association (KODISA)

This is an Open Access article distributed under the terms of the Creative Commons Attribution NonCommercial License (https://creativecommons.org/licenses/by-nc/4.0/) which permits unrestricted nocommercial use, distribution, and reproduction in any medium, provided the original work is properly cited. price has also been a popular activity, especially during the world economic crisis 2008-2010. In this period, the gold trading floors have been allowed to operate in the major cities in Vietnam. According to the statistics of the World Gold Council, Vietnam is in the major league of gold consuming countries. In detail, in 2015, Vietnam was ranked at Asia's 6th highest in gold demand, at the quantity as 63.4 tonnes, behind China (984.5 tonnes), India (848.9 tonnes), Thailand (90.2 tonnes), Saudi Arabia (84.5 tonnes) and marginally behind Iran (70.9 tonnes). In the world ranking, Vietnam's gold demand was 9th highest globally. At the end of the year 2017, the State Bank of Vietnam (SBV) estimated that the Vietnamese people reserve a quantity of gold between 300 and 500 tonnes.

However, monitoring and stabilizing of the domestic gold market have always been one of the difficult tasks of policymakers in Vietnam over time. Obsessed with the high inflation over the past three decades, gold has always been the first choice though by the Vietnamese people in the context of concerns about a depreciation of the domestic currency. It is from this phenomenon that the gold market in Vietnam has brought many profits for these precious metal 


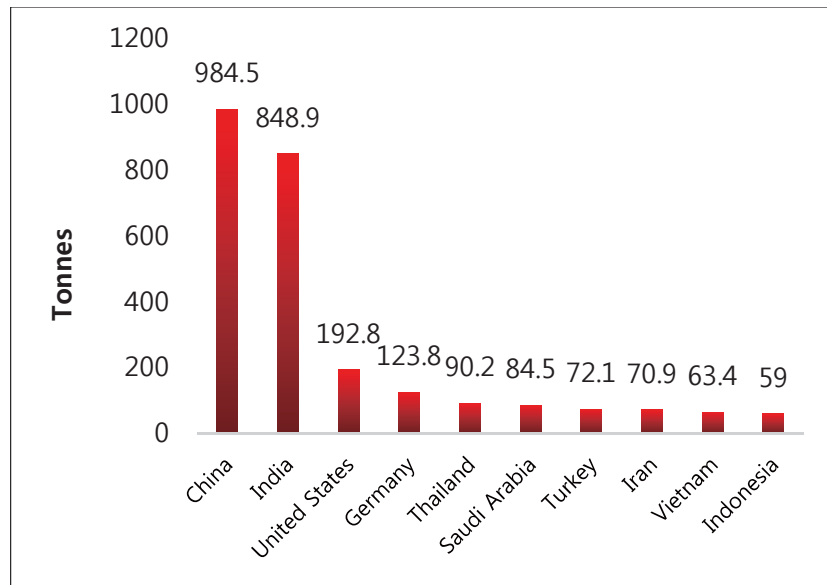

Figure 1: Top-ten countries in gold demand in 2015.

speculators. Vietnam's gold market has become very active in periods of economic crisis or when international gold prices are significantly lower than domestic gold prices. When there is an increase in the gap price between the international and domestic market. The speculators would fast raise import gold at low prices in the international market, then processing and selling at a higher price in the domestic market. Thus, the gold speculation has brought many profiting opportunities for people from gold trading in Vietnam. However, when the domestic gold market becomes more active, the Vietnamese monetary authorities will hard in struggling in order to stabilize the financial market in particular and the foreign exchange market. Besides, the import of gold will change the supply and demand for foreign currency and leads to fluctuations in the exchange rate regime.

In addition to the dollarization problem, the Vietnamese economy also faces goldization phenomenon which could reduce the effectiveness of the monetary policy. Fluctuations in gold prices will cause unpredictable fluctuations in the monetary market. Therefore, the study of the impact of the gold price on the macro variables of the monetary market is necessary to help policymakers manage more effectively. In particular, the relationship between gold price fluctuations and money demand is one of the urgent topics. There are some empirical studies focused on the literature of money demand in both developed countries (e.g., Mundell, 1963; Arango \& Nadiri, 1981; BahmaniOskooee \& Shabsigh, 1996; Bahmani-Oskooee, 2001) and developing countries (e.g., Akinlo, 2006; Baharumshah, Nohd, \& Masih, 2009). However, there is no evidence has mentioned the topic of the impact of the gap price between the international and domestic gold price on money demand in countries, especially in the top consuming gold countries in Asia. Therefore, in this study, we will try to fill with this research gap in the context of the Vietnamese market. Our investigated results are also useful references for policymakers to implement the management of the economy in the context of strong fluctuations in the domestic gold market.

The content of our paper includes five sections. In Section 2 , we represent the literature review and some empirical studies. Section 3 shows the methodology and data description. The estimation results of money demand function in the long run and the short run are introduced and discussed in Section 4. Finally, Section 5 reports some conclusions and implications for the policymakers.

\section{Overview of the Gold Market in Vietnam}

According to Asian cultural traditions, gold always plays an important role to represent wealth, prosperity or even power of households. Naturally, Vietnamese households have a habit of using gold as a medium of exchange, store of value, and an informal unit of account. In high-value asset transactions, such as real estate, Vietnamese people especially prefer to use gold as a medium of exchange (or a payment intermediary). This is the basic reason for Vietnam to be considered a high potential gold market in Asia. In addition, hyperinflation episodes (e.g., in the 1980s) are also an important reason making this metal is a preferred tool of the Vietnamese households to help protect assets against the devaluation of the domestic money. Due to the large demand, gold is also considered a special commodity to help many speculators seek profits through the transactions of gold to benefit from taking advantage of market price differences between international and domestic market.

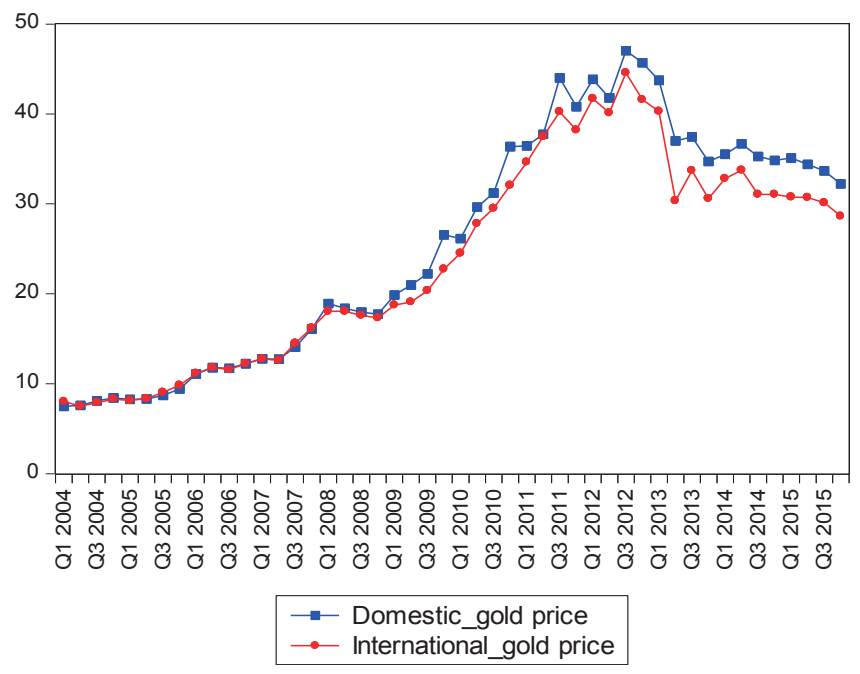

Figure 2: Comparison between the domestic gold price and international gold price in Vietnam in the period of 2004-2016. 
In many periods, when people increase reserving in gold, this is not a positive signal for the economy. Instead of transferring resources (e.g., financial capital, assets) into the investment process as well as business activities, the resources sleeps in the gold reserves of households or use for speculation target in the gold market. Therefore, the Vietnamese government always pays attention and regularly control the domestic gold market through its policies. The government's market regulations are aimed at minimizing gold speculation in the market and reducing the goldization of the economy.

In order to meet the rising demand for gold by the people, domestic gold enterprises will urgently import gold from the international market. After that, domestic businesses reprocess, manufacture and sell gold to the people. In Vietnam, the domestic gold price is always higher than the international gold price depending on the macroeconomic situation in the domestic market. Many times due to the strong demand for gold out-distance the supply capacity as well as temporary delays or interruptions in gold imports, the gold price in the domestic market tends to go far beyond the gold price in the international market. In many periods, the large gap between the domestic gold price and the international gold price were closely related to the instability of the Vietnamese monetary market. During these periods, people tend to withdraw bank deposits into cash to participate in speculation from the significantly higher in domestic gold prices comparing international gold prices (VnExpress, 2017). For example, in 2014, there was an especial exchange session when the domestic gold price was higher than the international price over VND 7 million per Luong (Luong is an official unit of gold in Vietnamese market).

Gap_gold price

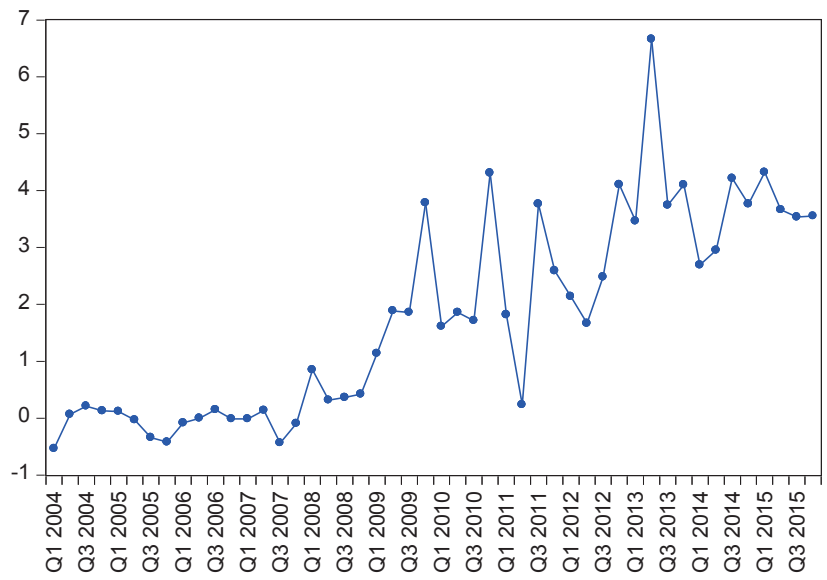

Due to the importance of the gold market for the stability of the monetary market as well as macroeconomic stability, the government has many legal documents to manage the gold market in Vietnam. One of the early documents is Decree 174/1999/ND-CP issued by the government in 1999 to manage gold trading activities. In this decree, gold trading activities were defined as the manufacture, processing of gold products, purchase, export, and import of gold in accordance with the current law. In 2003, an important part of the contents of Decree 174/1999/ND-CP was adjusted by the government with Decree 64/2003/ND-CP in order to better manage some aspects of the domestic gold market.

By the year of 2012, in the context of the fast development of Vietnam's gold market, the Government issued the Decree 24/2012/ND-CP to further improve the effectiveness of monitoring for economic activities relating to gold business in Vietnam. In particular, Decree 24/2012 /ND-CP has expanded the gold trading activities including trading activities on gold accounts (based on the Internet system) and derivatives. In the post-crisis period of the world economic crisis (in 2008), the gold market of Vietnam has a strong fluctuation when gold becomes a popular speculative tool to make profits of many components including business companies, gold retail stores, and households. In detail, the Decree 24/2012/ND-CP emphasizes a number of important contents, (i) The State Bank of Vietnam is the focal point to implement the unified management of gold trading activities in Vietnam, (ii) the government implemented monopoly in manufacture, business, raw material gold export, and import of raw material gold for processing, (iii) This Decree allows the State Bank of Vietnam to implement to stabilization the gold market through licensing activities of gold trading in the domestic market, organization of export gold, import of raw gold, organization of gold mobilization. In addition, the State Bank of Vietnam only recognized the brand of SJC gold of the Saigon Jewelry Company (the largest gold producer in the domestic market) as a national gold brand.

The government's efforts have gradually brought Vietnam's gold market into stability process. However, due to the large demand in the gold market, the fluctuations in this metal market always brings much concern to the policymakers in Vietnam. Besides, the gap between the domestic and international gold price is always an attractive speculation channel for traders to make profits. The gap between domestic and international gold price, in general, has affected the stability of the monetary market through its impacts on the money demand of the economy to serve speculative activities in the market.

Figure 3: The gap between domestic gold price and international gold price in Vietnam in the period of 2004-2016. 


\section{Literature Review}

The money demand is an important issue in economics so there are many studies have been done in both theoretical and empirical studies. However, there are very few studies that have taken gold as the explanatory variable of the money demand function. Especially, there is no research has mentioned the impact of the gap between domestic and international gold price on money demand.

The theoretical framework of the money demand function shows that the earliest studies were conducted in developed economies. One of the first studies made by Mundell (1963) who argued that the demand for money depended on the income and the interest rate. However, the study result also implied that flexible exchange rate regime would have an impact on the money supply of the economy (and money demand) when the governments tried to control the exchange market by their monetary policy. The research result of Arango and Nadiri (1981) suggested that the money demand in an open economy was affected by a number of macro variables, including domestic income, domestic interest rate, and price expectation, as well as some foreign variables such as exchange rate and foreign interest rate. Bahmani-Oskooee (1991) analyzed the money demand function in the UK including real income, nominal interest rate, and real effective exchange rate. In another empirical study, Bahmani-Oskooee and Shabsigh (1996) examined the money demand function in the case of the Japanese economy. The function includes macroeconomic variables such as real income, nominal interest rate, and nominal effective exchange rate. Not only in developed economies, but studies of money demandwere also gradually being experimented in the case of developing countries. An example is Akinlo's research (2006), the author used the Nigerian data and showed that the money demand was cointegrated with domestic income, interest rate and exchange rate in this economy. In the case of the Chinese economy, Baharumshah, Nohd, and Masih (2009) analyzed the money demand with some determinants including real income, inflation, foreign interest rates, and stock prices.

However, there are quite a few studies that have taken gold as an explanatory variable of the money demand function. Murphy (1992) from the World Gold Council had an overview of the important monetary role of gold in the economy. According to Coulson (2005), gold has gradually been used as a popular investment channel in addition to the roles of this metal in the store of value of assets. Besides, Emmrich and McGroarty (2013) also argue that after many years in the wilderness, gold investment has come back into fashion of investment. In empirical research in emerging economies, Liu (2016) also showed that middle class incremental acquire gold for both consumption and investment targets.

There are some research questions will be expected to answer in our paper. For example, acting as an investment channel (speculation) so 'Does gold price affect money demand?' or 'Does the gap between domestic and international gold price affect the money demand in Vietnam?'. In fact, there are only a few studies that add international gold price in the money demand function, however, we cannot any research has mentioned the impact of the gap between domestic and international gold prices on the demand money. Finally, our research will expect to contribute to expanding the theoretical framework of the money demand function in the case of economies having a large gold market as well as popular consumption habits in this important metal.

\section{Data and Methodology}

\subsection{Methodology}

Based on the previous results, in order to study the impact of the gap between domestic and international gold price on money demand, we represent the money demand function by the equation form as below:

$$
M_{t}=\beta_{0}+\beta_{1} Y_{t}+\beta_{2} I N F_{t}+\beta_{3} R E E R_{t}+\beta_{4} G A P \_G O L D_{t}+\varepsilon_{t}
$$

Where: $M$ is the money demand, $Y$ is the Gross domestic product (GDP) which is a proxy for the domestic income, INF is the inflation rate and REER is the real effective exchange rate. GAP_GOLD is represented by the gap between the domestic and international gold price in the Vietnamese market. Finally, $\varepsilon$ is the error term of the equation.

To test long-term cointegrated relationships, the paper applies the Johansen (1988) to examine the existence of this relationship in the long run between variables in the demand function. The Johansen method concludes the cointegration based on two likelihood ratio criteria including the Maximum Eigenvalue and Trace statistics. These criteria are used to test the number of cointegration vectors in the model. The likelihood ratio values are normally calculated as the following functions:

$$
\begin{aligned}
& \lambda_{\text {Maximum }}=-\mathrm{T} \ln \left(1-\lambda_{\mathrm{r}+1}\right) \quad r=0,1,2, \ldots, \mathrm{p}-1 \\
& \lambda_{\text {Trace }}=-\mathrm{T} \sum_{\mathrm{r}+1}^{\mathrm{p}} \ln \left(1-\lambda_{\mathrm{i}}\right) \quad r=0,1,2, \ldots, \mathrm{p}-1
\end{aligned}
$$


where, $T$ is the sample size and $\lambda_{i}\left(i=1,2, \ldots, p ; \quad \lambda_{1}>\lambda_{2}\right.$ $\left.>\ldots>\lambda_{p}\right)$ is presented as the Eigenvalue criteria. The

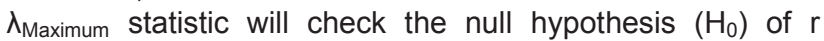
cointegrating against the alternative hypothesis $\left(\mathrm{H}_{1}\right)$ that there are $(r+1)$ cointegrating vectors. In the $\lambda_{\text {Maximum }}$ test, the null hypotheses to be tested are in a checking procedure of the following: $\mathrm{H}_{0}: r=0$ against $\mathrm{H}_{1}: r=1 ; \mathrm{H}_{0}: r \leq 1$ against $H_{1}: r=2 ; \ldots ; H_{0}: r \leq p-1$ against $H_{1}: r=p$. For example, if $\mathrm{H}_{0}: r=0$ is rejected at $95 \%$ based on the critical value and $\mathrm{H}_{0}: \mathrm{r} \leq 1, \ldots$ and $\mathrm{H}_{0}: \mathrm{r} \leq \mathrm{p}-1$ are all not rejected at the same value, then the $\lambda_{\text {Maximum }}$ test statistic indicates the existence of at most one cointegrating vector.

After that, the $\lambda_{\text {Trace }}$ statistic is used to check the null hypothesis $\left(\mathrm{H}_{0}\right)$ that has at most $\mathrm{r}$ co-integrating vectors in the equation. The testing result implies the number of cointegrating vectors is less than or equal to $r$. In the case of the $\lambda_{\text {Trace }}$ statistic, the null hypotheses to be tested are in a checking procedure including $\mathrm{H}_{0}: r=0$ against $\mathrm{H}_{1}: r \geq 1 ; \mathrm{H}_{0}$ : $r \leq 1$ against $H_{1}: r \geq 2 ; \ldots ; H_{0}: r \leq p-1$ against $H_{1}: r=p$. For example, we have $\mathrm{H}_{0}: r=0$ is rejected at $95 \%$ based on the critical value and $H_{0}: r \leq 1, \ldots$ and $H_{0}: r \leq p-1$ cannot be rejected at the same value, the $\lambda_{\text {Trace }}$ test concludes the existence of at least one cointegrating vector.

\subsection{Data Source}

In this study, we use a quarterly database collected from the first quarter of 2004 to the fourth quarter of 2016 . The time-series database includes 52 observations. The money demand $(M)$ is represented by $M 2$, sourced from the State Bank of Vietnam (unit is VND trillions); Domestic income $(Y)$ is the Gross domestic product (GDP) at the constant prices of 1994 sourced from the General Statistics Office of Vietnam (unit is VND trillions). The inflation rate (INF) is calculated by the Customer Price Index (CPI) sourced from the General Statistics Office of Vietnam (unit is \%).

The real exchange rate (REER) is calculated according to this formula:

$$
\operatorname{REER}=\sum_{\mathrm{i}=1}^{\mathrm{n}}\left(\mathrm{e}_{\mathrm{it}} \frac{\mathrm{P}_{\mathrm{it}}}{\mathrm{P}_{\mathrm{t}}}\right)^{\mathrm{wit}}
$$

In this function, e is the nominal exchange rate. However, in this study, REER is only based on the nominal exchange rate between VND and USD. In our function, $\mathrm{P}$ (Price index) is replaced by $\mathrm{CPI}$ (Consumer price index). The nominal exchange rate of VND and USD comes from the State Bank of Vietnam, the CPI of Vietnam is come from the General
Statistics Office of Vietnam and the US'S CPI is taken from the IFS database (International Financial Statistic) of International Monetary Fund (IMF).

The gap between domestic and international gold prices is denoted by Gap_Gold. The international gold price is collected from the database of the Federal Reserve Bank of St. Louis. The international gold price in USD is converted into VND based on the nominal exchange rate of VND/USD which sourced from the State Bank of Vietnam. Besides, the unit of international gold is ounce which converted into the domestic unit of gold in Vietnam (Luong). In which, an ounce is equal to 0.833 Luong. Accordingly, the formula for converting the international gold price into the Vietnamese currency is reported as follows:

$$
\begin{aligned}
& \text { One ounce gold } \\
& \qquad=0.833^{*} \text { one Luong * nominal exchange rate }
\end{aligned}
$$

Domestic gold price is the price of the SJC gold sold by Saigon Jewelry Company Limited (this is the biggest gold trading company in Vietnam market and is also the brand defined by the government of Vietnam as a national trademark of the Vietnamese gold standard). The unit of the gap between domestic and international gold prices is VND million. The formula defines the gap between the domestic and international gold price in Vietnam is presented as follows:

$$
\begin{aligned}
\text { GAP_GOLD }= & \text { Gold price in domestic market } \\
& \text { - Gold price in international market }
\end{aligned}
$$

Besides, the descriptive statistics and the graphs of the variables are shown below.

Table 1: Descriptive statistics of the variables

\begin{tabular}{|c|c|c|c|c|c|}
\hline Statistic & $\mathbf{M}$ & $\mathbf{Y}$ & INF & REER & GAP_GOLD \\
\hline Mean & 2713.8 & 158.65 & 1.986 & 6827.7 & 1.6917 \\
\hline Median & 2270.1 & 140.41 & 1.630 & 6496.4 & 1.6397 \\
\hline Maximum & 7052.5 & 334.35 & 7.686 & 8825.5 & 6.6642 \\
\hline Minimum & 397.33 & 71.080 & -0.017 & 5756.3 & -0.5454 \\
\hline Std. Dev. & 1989.2 & 64.727 & 0.0204 & 1034.0 & 1.7957 \\
\hline Skewness & 0.6597 & 1.1645 & 0.8794 & 0.7391 & 0.5304 \\
\hline Kurtosis & 2.2324 & 3.6964 & 3.6338 & 1.9590 & 2.2681 \\
\hline Jarque-Bera & 5.0487 & 12.803 & 7.4283 & 7.0824 & 3.5995 \\
\hline Probability & 0.0801 & 0.0016 & 0.0243 & 0.0289 & 0.1653 \\
\hline Observations & 52 & 52 & 52 & 52 & 52 \\
\hline
\end{tabular}


Money_demand

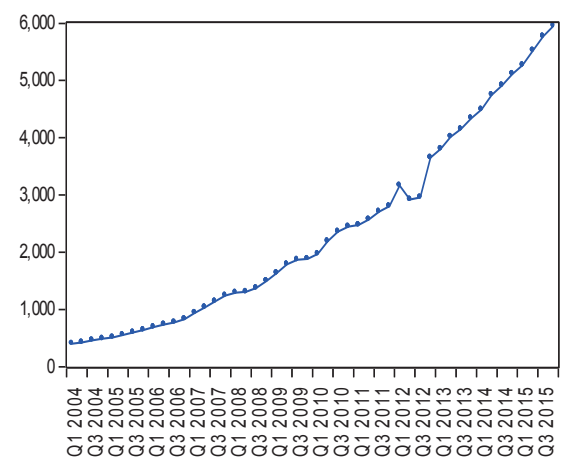

Gap_gold price

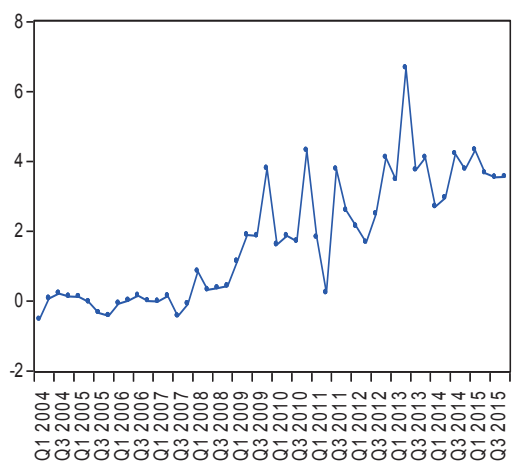

GDP

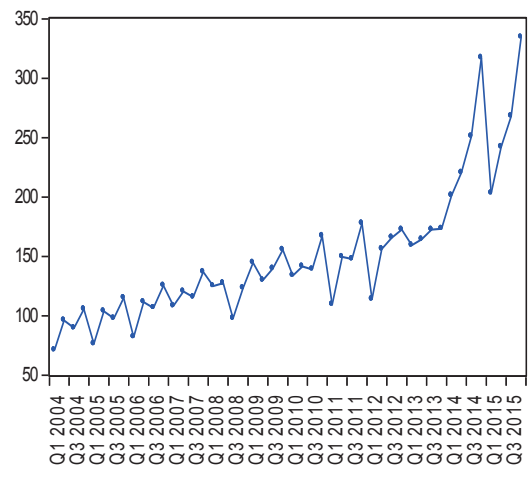

Inflation

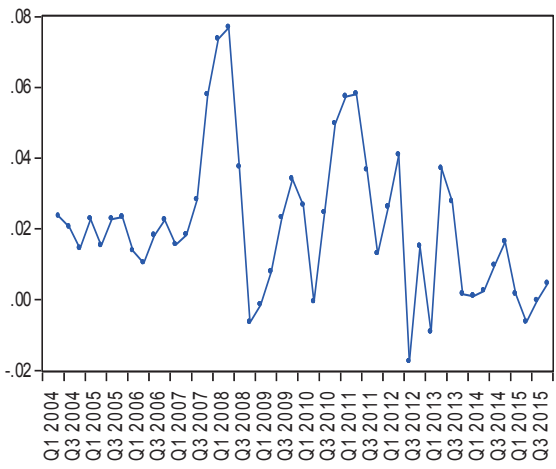

REER

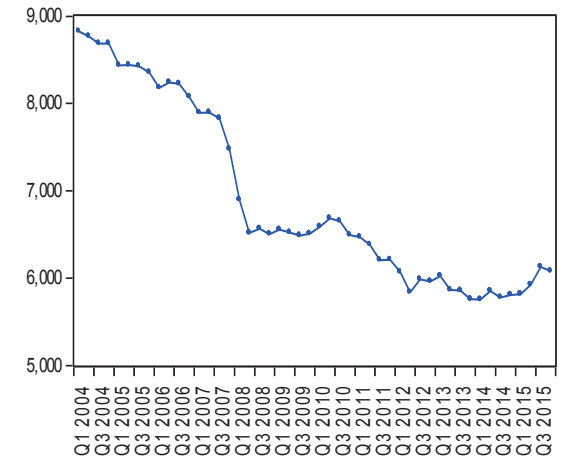

Figure 4: Graphs of the variables

Table 2: Result of Unit root test of the variables

\begin{tabular}{|c|c|c|c|}
\hline Variable & With intercept & With trend and intercept & Without constant \\
\hline Money demand (M) & $4.517619^{* * *}$ & -0.083879 & $7.635025^{* * *}$ \\
\hline Real Gross Domestic Product (Y) & 1.963478 & 0.005374 & 3.427746 \\
\hline Inflation (INF) & $-3.470367^{\star *}$ & $-3.635631^{* *}$ & $-2.410484^{\star *}$ \\
\hline Real Exchange rate (Reer) & -1.835591 & -1.129196 & $-2.033896^{\star *}$ \\
\hline Gap price between domestic and international gold price(Gap_Gold) & -1.550755 & $-5.605466^{* * *}$ & -0.547895 \\
\hline
\end{tabular}

Note: * indicates significance at 0.10 level, ${ }^{* *}$ indicates significance at 0.05 level, ${ }^{* * *}$ indicates significance at 0.01 level.

\section{Results and Discussion}

\subsection{Unit Root Test and Cointegration Test}

The paper applies the Augmented Dickey-Fuller (ADF) method to test the unit root of variables in money demand function. According to Dickey and Fuller (1979), the ADF test is chosen because this method allows the less restrictive assumptions for the time series in the function than others. There are three conditions, including (1) with intercept, (2) with the trend and intercept, and (3) without constant, are applied for the technique. However, the testing results show that the money demand variable is stationary at a significance level of $1 \%$ (with intercept and trend and intercept), the inflation variable also is stationary at a significance level of $5 \%$ (with all condition testings). Besides, the real exchange rate is stationary only in the without constant form at a significance level of $5 \%$ as well as the Gap-Gold at a significance level of $1 \%$ with the trend and intercept condition. So the results suggest there maybe cannot conclude about the existence of the cointegration relationship at the level $\mathrm{I}(0)$ among variables in the money demand equation. The unit root test results are reported in the below table.

The result of unit root test shows that the time-series variables do not stationary at the same level. This evidence leads to concern that the regression results of long-term relationships of variables will be counterfeited. To confirm 
the long-term relationship between the variables of the money demand function, the Johansen cointegrated method (1988) was used for the testing process. The test results indicate the existence of at least two cointegrated vectors with Trace statistics and the existence of at least a cointegrated vector by Max-Eigen statistics at the significance of $5 \%$ level. The testing result of Johansen (1988) method confirmed the existence of a long-term relationship between money demand and real income, inflation, real exchange rate, and the gap between the domestic and international gold price in the case of Vietnam.

Table 3: Results of the Johansen cointegration test

\begin{tabular}{|l|c|c|c|c|c|}
\hline Rank null hypothesis & $\mathbf{r} \leq \mathbf{0}$ & $\mathbf{r} \leq \mathbf{1}$ & $\mathbf{r} \leq \mathbf{2}$ & $\mathbf{r} \leq \mathbf{3}$ & $\mathbf{r} \leq \mathbf{4}$ \\
\hline \multirow{2}{*}{ Trace test } & $99.33^{*}$ & $55.44^{*}$ & 29.23 & 11.15 & 0.912 \\
& {$[0.000]$} & {$[0.008]$} & {$[0.058]$} & {$[0.202]$} & {$[0.339]$} \\
\hline \multirow{2}{*}{ Max-Eigenvalue test } & $34.88^{*}$ & 26.21 & 18.08 & 10.23 & 0.913 \\
& {$[0.037]$} & {$[0.074]$} & {$[0.216]$} & {$[0.193]$} & {$[0.339]$} \\
\hline
\end{tabular}

\subsection{Correlation Analysis}

The correlation analysis is always considered as one of the most simple quantitative methods, however, the results are really useful to fast observe the relationships among variables. According to the literature of the econometrics, a correlation is a single number that describes the degree of relationship between two variables. The correlation results show the correlation coefficients between amongst of the variables in the econometric equation. The correlation values between variables in the money demand function are represented in the following table.

Table 4: The correlation matrix results

\begin{tabular}{|c|c|c|c|c|c|}
\hline Variables & $\mathbf{M}$ & $\mathbf{Y}$ & INF & RER & GAP_GOLD \\
\hline $\mathrm{M}$ & 1.0000 & & & & \\
\hline $\mathrm{Y}$ & 0.0909 & 1.0000 & & & \\
\hline INF & -0.3786 & -0.3662 & 1.0000 & & \\
\hline RER & -0.7957 & -0.6717 & 0.1482 & 1.0000 & \\
\hline GAP_GOLD & 0.5705 & 0.5337 & -0.1762 & -0.7055 & 1.0000 \\
\hline
\end{tabular}

The results of the correlation matrix analysis have initially shown some issues about the relationships between variables in the demand function in Vietnam. First, the most important concerning in this study is the direction of the relation between the Gap_Gold and money demand. The relation coefficient between Gap_Gold and money demand is a positive sign (0.5705) which shows the consistency of statistics with the assumption in the previous section about the direction of the impact of Gap_Gold variable on money demand in Vietnam.
Thus, the fact that the gold in Vietnam is known as a means of payment or reserve but also a speculative commodity to make a profit through trading in the market. If the gap between domestic and international gold price increases, it means that the profit gained from the gold trading in the Vietnamese market will also increase. Many households will withdraw cash from their bank accounts to make short-term gold purchases aimed at making a profit with the fluctuated waves of gold prices. So, when the gap between domestic and international gold price increases, people will increase the demand for money (that is, raise the amount of cash held in hand). In the other hand, when the gap between domestic and international gold price decreases, the opportunities for finding profit decreases as well, as a result, people will deposit money into bank accounts and the demand for money will reduce.

Besides, the correlation matrix analysis results continuously show that domestic income has a positive impact on money demand, however, inflation has a negative impact on money demand. These correlation coefficients are consistent with the theoretical framework as well as with some previous empirical studies of the money demand function. Finally, the real exchange rate has a negative relationship with money demand, implying that when the domestic currency depreciates relative to the foreign currency, the demand for money will decrease. This is also in line with the economic reality because the devaluation of the domestic currency will reduce the motivation of people to keep money and lead to a decrease in demand for money.

\subsection{Regression Results}

In the previous sections, some issues on the structure of money demand function as well as the relationship between some variables and money demand in Vietnam have gradually been clarified. The result of Johansen test (1988) has confirmed the existence of at least one long-term cointegration relationship among such variables as the domestic income, inflation, real exchange rate, the gap between the domestic and international gold price and money demand in the Vietnamese economy. Furthermore, the correlation results also help to fast analysis the correlation relationships among the variables in the research model.

Next, in this section, we will estimate the equation (1) to identify the coefficients which exactly describe the long-term relationships between money demand and among macro variables in Vietnam. However, in many cases of quantitative analysis, we are not sure whether our regression result is correctly specified. So some diagnostic tests will be done for the estimated results to confirm that these results are free of the serial autocorrelation, the 
heteroskedasticity as well as the normal distribution phenomenon. The long-term estimated results, as well as the diagnostic tests, are described in the below table. Besides, the next issue is the question that 'Is whether the regression is better if adding more independent variables in the model?'. According to Gujarati (2004) who has a recommendation about adding new variables to an econometric model, the suggestion implies that it is worth adding a new variable to the model when gives an Adjusted $\mathrm{R}$ square greater, and conversely (Gujarati, 2004, p.264). Based on the received results, we can conclude that the adding variables for the estimation are good because they increase the Adjusted $\mathrm{R}$ square values obtained from the estimated models.

Table 5: The regression results Dependent Variable: Money demand

\begin{tabular}{|c|c|c|c|c|}
\hline \multirow{2}{*}{ Variables } & Model 1 & Model 2 & Model 3 & Model 4 \\
\cline { 2 - 5 } & \multicolumn{4}{|c|}{ Coefficient } \\
\hline \multirow{2}{*}{ Constant } & $977.012^{* * *}$ & $-946.452^{* * *}$ & $-787.057^{* *}$ & $3497.43^{* * *}$ \\
& {$[5.3246]$} & {$[-3.7977]$} & {$[-2.5961]$} & {$[3.3077]$} \\
\hline Y & & $17.6601^{* * *}$ & $17.1944^{* * *}$ & $14.7463^{* * *}$ \\
& & {$[8.7875]$} & {$[8.2257]$} & {$[7.8785]$} \\
\hline INF & & & -4807.63 & $-7568.79^{*}$ \\
& & & {$[-1.1398]$} & {$[-2.0751]$} \\
\hline REER & & & & $-0.5130^{* * *}$ \\
& & & & {$[-4.1782]$} \\
\hline GAP_GOLD & $786.941^{* * *}$ & $389.641^{* * *}$ & $392.804^{* * *}$ & $206.009^{* * *}$ \\
& {$[10.495]$} & {$[6.0401]$} & {$[6.0480]$} & {$[2.8991]$} \\
\hline R-squared & 0.7054 & 0.8915 & 0.8921 & 0.9238 \\
\hline Ajusted R-squared & 0.6990 & 0.8867 & 0.8846 & 0.9165 \\
\hline LM test & 7.5579 & 0.5723 & 0.5941 & 2.474 \\
& $(0.0015)$ & $(0.5685)$ & $(0.5567)$ & $(0.097)$ \\
White test & 16.7446 & 2.67543 & 1.7784 & 1.1448 \\
Nomality test & $(0.0000)$ & $(0.0346)$ & $(0.1058)$ & $(0.3605)$ \\
& 1.28876 & 0.02203 & 0.1616 & 0.4166 \\
& $(0.5249)$ & $(0.9890)$ & $(0.9223)$ & $(0.8119)$ \\
\hline
\end{tabular}

Note: ${ }^{* * *},{ }^{* *},{ }^{*}$ : indicate the significant statistics at $1 \%, 5 \%$ and $10 \%$ level

First, the evidence is quite clear when the regression coefficients of the variable Gap_Gold are positive in all estimation results of the models. This proves that the gap between the domestic and international gold price really has a positive impact on money demand in Vietnam during the study period. Besides, the evidence also is quite obvious when the regression coefficients reach the statistical significance of $1 \%$ level in all estimated results. So the hypothesis of the research model has been confirmed in the case of Vietnam. This evidence suggests that, if the gap between domestic and international gold prices increases, it also will raise the money demand of households because gold is a popular speculative commodity to seek short-term profits in the market.
In fact those households will withdraw bank deposits to participate in the gold speculative market to earn a shortterm profit before the fluctuations of gold price. This action is easily understood because the waves of the gold price always fast come and fast go as well. So if the gap between domestic and international gold prices drops, the gold market will gradually reduce heat and cash will come back to the bank. So gold also use as investment channel in Vietnam (see Coulson, 2005). Therefore, the decrease in the gap between domestic and international gold price will reduce the demand for money. Besides, Vietnam is ranked in low-middle income group so the Vietnamese people prioritize to the gold market is clearly understood (see Liu, 2016). To clarify the relationship between these two variables, a scatter graph is drawn with statistics with the horizontal axis as the gap gold price and the vertical axis denotes the money demand. The observed results on the graph show a clear positive correlation between two variables during the study period. The analysis by the graph helps a good link with the regression results in the previous parts.

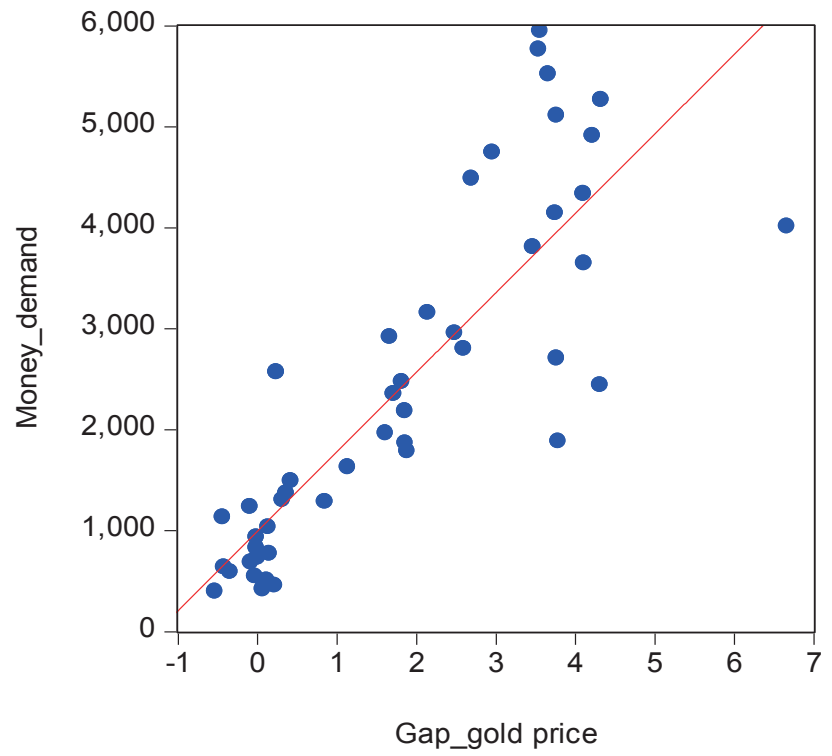

Figure 5: Graph of correlation between money demand and Gap_Gold price

According to the discussion of Gujarati (2004, p.264), we have 4 estimation results which are well presented. However, which result is the best one? Compare the results of diagnostic tests (including serial correlation, heteroskedasticity and the residual normality test) as well as the value of adjusted R-squared obtained from the regression results. The conclusion is that model 4 is the best one with the existing statistics. The regression result 
according to model 4 pass all diagnostic tests when concluding that the estimated model is free of serial correlation, heteroskedasticity, as well as the normal distribution of residuals. Besides, the adjusted R-squared of model 4 is the largest value compared to others, which indicates that this is the optimal model (Gujarati, 2004).

In addition, the regression coefficients of other variables are consistent with the theory of money demand function as well as some empirical studies. The results show that domestic income positively affects money demand with the statistical significance of $1 \%$ level. This evidence is supported by some previous results (e.g., Arango \& Nadiri, 1981; Bahmani-Oskooee, 1991; Akinlo, 2006). This result reflects that the Central bank of Vietnam needs to balance the money supply to match the increase in the quantity of money demand in the context of positive economic growth in Vietnam in the coming time. Nextly, inflation has a negative impact on money demand, reflecting the Vietnamese people fear and oppose the depreciation of the domestic currency by reducing money demand. The evidence in Vietnam also is quite consistent with the reality of developing countries which often face with the speedingup of the inflation rate (see Baharumshah, Nohd, \& Masih, 2009).

Finally, the regression coefficient of the real exchange rate has a negative sign that implies the negative impact of this variable on the money demand in Vietnam. The increase of real exchange rate indicates that the purchasing power of the domestic currency has relatively decreased to the foreign currency. Our finding in the case of the Vietnamese economy is assisted by some previous results in some other developing countries (eg, Akinlo, 2006). In this case, the Vietnamese people will tend to reduce the reserve of the domestic currency as well as replace it with gold, high-value assets (such as real estate) or foreign currencies.

\section{Conclusions and Policy Implication}

Factors affecting money demand is an important issue that policymakers need to consider in order to control the macroeconomic environment of an economy. Unlike the most previous studies, our paper aims to study the impact of the gap between domestic and international gold price on money demand in Vietnam, which now is a country in the top-ten gold markets worldwide. The research results confirm the existence of a long-term relationship between money demand and explanatory variables including domestic income, inflation, real exchange rate and the gap between domestic and international gold price gold in the case of Vietnam. Furthermore, the gap between domestic and international gold price has a positive impact on money demand in this economy. Our finding is a significant contribution to the expansion of the theoretical framework of the money demand function in the context of large gold consuming countries. In addition, some empirical impacts found in the study are relevant and supported by some previous studies. In particular, domestic income has a positive impact on the money demand, on the other hand, both inflation and real exchange rate also have a negative impact on money demand in Vietnam during the study period.

Based on the experimental results, some policy implications are drawn in order to stabilize the money demand function in countries which have a large gold market. Our results conclude that the Vietnamese policymakers need to have an annual target about the stabilize the gold market to minimize speculation, thereby, enhance stabilize money demand as well as the monetary market. First, policymakers need to pay special attention to fluctuations in the gold price in the market in order to take stable actions through the use of national gold funds to stabilize the market. Second, market monitoring offices need to have repressions for the speculators in the gold market, which can be seen as a kind of financial crime. Finally, the policymakers need to stabilize inflation as well as reduce the fluctuation of the real exchange rate, are also efforts to stabilize the gold market and thereby stabilize the domestic monetary market.

\section{References}

Akinlo, A. E. (2006). Stability of money demand in Nigeria: An Autoregressive distributed lag Approach. Journal of Policy Modeling, 28(4), 445-452.

Arango, S., \& Nadiri, M. I. (1981). Demand for money in open economies. Journal of Monetary Economics, 7(1), 69-83.

Bahmani-Oskooee, M. (1991). The demand for money in an open economy: The United Kingdom. Applied Economics, 23(6), 1037-1042.

Bahmani-Oskooee, M., \& Shabsigh, G. (1996). The demand for money in Japan: Evidence from cointegration analysis. Japan and the World Economy, 8(1), 01-10.

Baharumshah, A. Z., Nohd, S, H., \& Masih, A. M. M. (2009). The stability of money demand in China: Evidence from the ARDL model. Economic Systems, 33(3), 231-244.

Coulson, M. (2005). Gold as an investment. Applied Earth Science, 115(2), 122-128.

Dickey, D.A., \& Fuller, W.A. (1979). Distribution of the Estimators for Autoregressive Time Series with a Unit 
Root. Journal of the American Statistical Association, 74(366), 427-431.

Emmrich, O., \& McGroarty, F. J. (2013). Should gold be included in institutional investment portfolios? Applied Financial Economics, 23(19), 1553-1565.

Federal Reserve Bank of St. Louis (2018). Online database. Retrieved August 28, 2018 from https://www.stlouisfed.org/

Johansen, S. (1988). Statistical Analysis of Cointegration Vectors. Journal of Economic Dynamics and Control, 12(2-3), 231-254.

Government. (1999) Decree No. 174: Management of the gold business activities. Hanoi, Vietnam (in Vietnamese).

Government. (2003) Decree No. 64: Management of the gold business activities (advanced). Hanoi, Vietnam (in Vietnamese).

Government. (2012). Decree No. 24: Management of the gold business activities (advanced). Hanoi, Vietnam (in Vietnamese).

GSO. (2017). Statistics database. Retrieved October 22, 2017, from http://www.gso.gov.vn/Default_en.aspx? tabid $=766$.

Gujarati, D. N. (2004). Basic econometrics (4 ${ }^{\text {th }}$ Edition). New York, NY: McGraw-Hill.

IMF (2018). IMF data access to the macroeconomic and financial data (International Financial Statistics-IFS).
Retrieved April 15, 2018, from http://data.imf.org/?sk=4C514D48-B6BA-49ED-8AB952B0C1A0179B

Liu, J. (2016). Covered in Gold: Examining gold consumption by middle class consumers in emerging markets. International Business Review, 25(3), 739-747.

Mundell, A. R. (1963). Capital mobility and stabilization policy under fixed and -flexible exchange rate. Canadian Journal of Economics and Political Science, 29(4), 475485.

Murphy, R. (1992). The Monetary Role of Gold. Interdisciplinary Science Reviews, 17(3), 234-238.

SBV. (2018). Online database. Retrieved August 18, 2018, from https://www.sbv.gov.vn/webcenter/portal/en/home/ sbv/statistic

Statista (2015). Consumer gold demand in major consuming countries in 2015 (in metric tons). Retrieved July 20, 2018, from https://www.statista.com/statistics/299638/goldconsumer-demand-by-top-consuming-country/

VnEpress. (2017). Vietnam considers plan for gold trading floor to curb hoarding. Hanoi, Vietnam. Retrieved July 6 , 2018, from https://e.vnexpress.net/news/business/vietnamconsiders-plan-for-gold-trading-floor-to-curb-hoarding3526165.html. 